\title{
A FIELD INVENTORY AND COLLECTIONS SUMMARY OF HERPETOFAUNA FROM THE SUTTER BUTTES, AN “INLAND ISLAND” WITHIN CALIFORNIA’S GREAT CENTRAL VALLEY
}

\author{
Eric O. Olson $1,2,4$, Jackson D. Shedd2,3, and Tag N. Engstrom ${ }^{2}$
}

\begin{abstract}
The Sutter Buttes (Buttes) are a small, isolated mountain range in the Great Central Valley of California. Systematic study of the fauna and flora of this unique habitat has been limited by the private ownership of the entire mountain range. As a result, much of our knowledge about the herpetofauna of the Buttes is based on isolated observations and scattered museum records, most over 4 decades old. In this study, we present an updated inventory of the herpetofauna of the Buttes, based on a 2-year field survey within the boundaries of the first publicly protected property within the Buttes (Sutter Buttes State Park) and a comprehensive survey of museum specimens. The objective of this study was to develop a current herpetofaunal species list for the Buttes as a whole and the park specifically. We verify the occurrence of 16 previously identified herpetofaunal species within the park and provide evidence for 3 additional species. We also provide the first record of the widely invasive Pond Slider (Trachemys scripta); clarify the status of a previous misidentification of a federally threatened species, Giant Gartersnake (Thamnophis gigas); and provide evidence for the probable extirpation of 2 California Species of Special Concern, the Foothill Yellow-Legged Frog (Rana boylii) and Blainville's Horned Lizard (Phrynosoma blainvillii). Therefore, our species list for the Buttes includes 20 herpetofaunal species. Museum specimens from the Buttes are located at 8 museums, with the majority at the California State University, Chico Vertebrate Museum. Sixteen of the 22 herpetofauna species extant or recently extirpated from the Buttes are represented by museum vouchers, with only 11 having tissue samples. This study sets an updated baseline for the further study and monitoring that will be required to facilitate effective management and conservation of the unique Sutter Buttes.
\end{abstract}

REsumen.-Sutter Buttes (Buttes) es una pequeña y aislada cordillera montañosa en el Gran Valle Central de California. El estudio sistemático de la fauna y la flora de este hábitat único se ha visto limitado debido a que toda la cordillera es propiedad privada. Como resultado, gran parte del conocimiento de la herpetofauna de la cordillera se basa en observaciones aisladas y registros dispersos de museo, la mayoría con más de cuatro décadas de antigüedad. En este estudio, presentamos un inventario actualizado de la herpetofauna de la cordillera, basado en un estudio de campo de dos años dentro de los límites de la primera propiedad de protección pública en la zona (Sutter Buttes State Park) y en una exhaustiva investigación de especímenes de museo. El objetivo de este estudio fue crear un listado de especies de herpetofauna presentes actualmente en la zona en general y en el parque en específico. Verificamos 16 especies de herpetofauna, previamente identificadas, en el Parque y mostramos evidencia de tres especies adicionales en el Parque. También proporcionamos el primer registro de la tortuga invasora Jicotea de Estanque (Trachemys scripta), clarificamos el estado de un error de identificación previo de una especie, amenazada a nivel federal, la serpiente Jarretera Gigante (Thamnophis gigas), y aportamos pruebas de la probable extirpación de dos especies de interés especial para California, la Rana Patas Amarillas de las Estribaciónes (Rana boylii) y el Camaleón de Blainville (Phrynosoma blainvillii). Por lo tanto, nuestro listado de especies para la cordillera incluye 20 especies de herpetofauna. Los especímenes de museo de la cordillera se encuentran en ocho museos, la mayoría en Museo de Vertebrados de Chico en la Universidad Estatal de California. Dieciseis de las 22 especies de herpetofauna existentes, o recientemente extirpadas, de la cordillera están representadas por comprobantes de museo, sólo 11 de ellas con muestras de tejido. Este estudio establece una base actualizada para su estudio y seguimiento futuro que será necesario para facilitar la gestión y conservación de una zona única como Sutter Buttes.

Without baseline information on species presence in an environment, it is impossible to assess changes in a community over time as that community is altered by natural events or disturbances resulting from human activities. As the human population in California increases, wildlife habitat will continue to be altered by, or lost to, development. This makes identifying and protecting unique landscapes, habitats, and species communities vital to the future of the state's wildlife and plant biota, a significant portion of which is endemic to the region.

One such unique location in California is the Sutter Buttes (Buttes) in northern Sutter County. The Buttes are the remnants of a once

\footnotetext{
${ }^{1}$ Center for Natural Lands Management, 27258 Via Industria, Suite B, Temecula, CA 92590

${ }^{2}$ Department of Biological Sciences, California State University, Chico, Chico, CA 95929

${ }^{3}$ Nevada Department of Conservation and Natural Resources, 901 S. Stewart St., Suite 5003, Carson City, NV 89701.

${ }^{4}$ Corresponding author. E-mail: eolson@ cnlm.org
} 


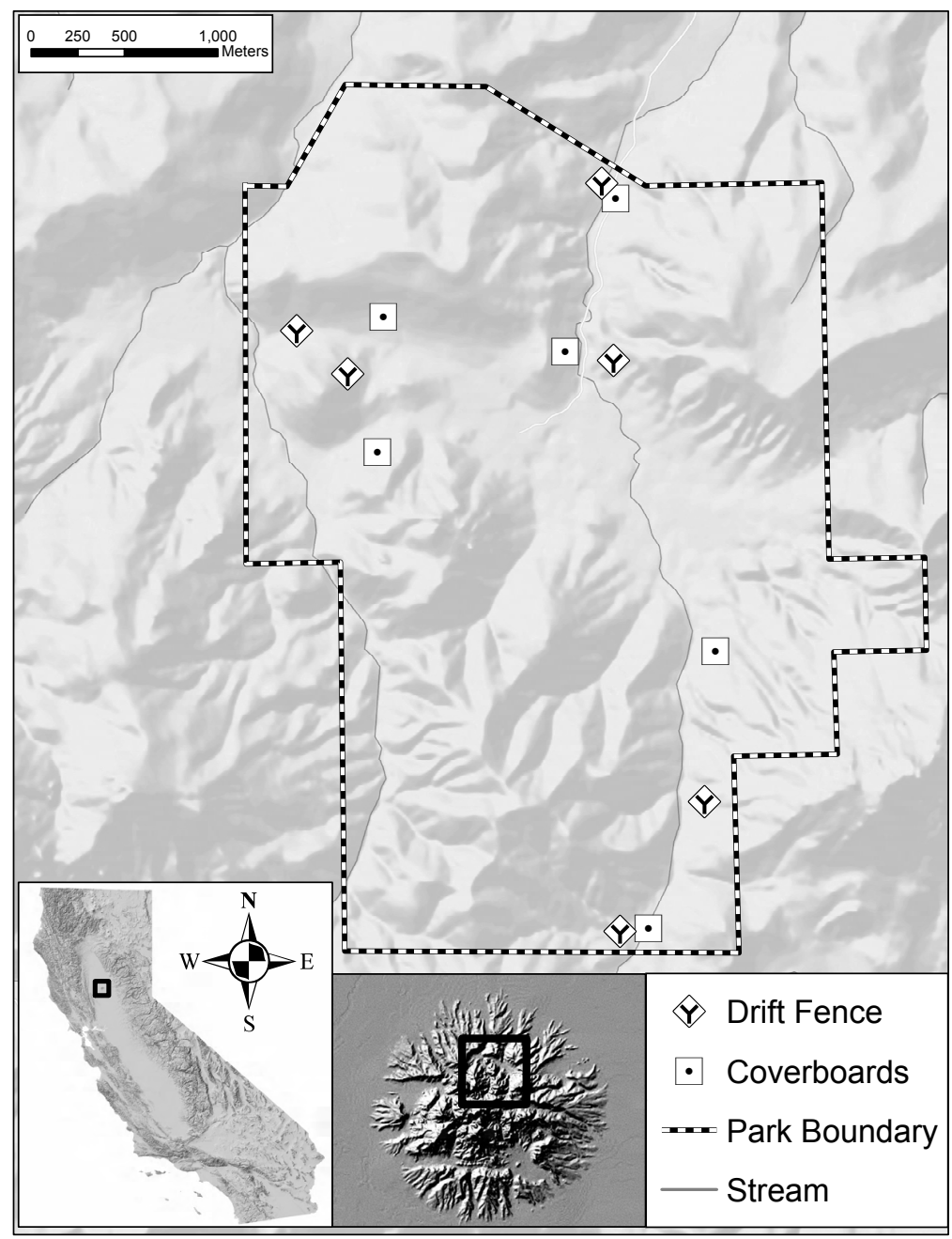

Fig. 1. Location of the Sutter Buttes within the Great Central Valley, California (inset lower left), detail of the Sutter Buttes with the study site bounded (inset lower middle), and study location with details of survey array locations within the park (main map).

much larger volcano in the heart of the Great Central Valley. They have been isolated from all other mountainous regions since their formation approximately 1.6 million years ago (Williams and Curtis 1977; Fig. 1). The Buttes offer a refuge for montane species in the expansive and otherwise topographically uniform Great Central Valley, leading Anderson (2004) to characterize the area as an "inland island." The isolated nature of the Buttes has led to a unique assemblage of species, many of which are montane species that have become isolated at the Buttes from their now-disjunct, wider-ranging populations elsewhere in the state (Anderson 2004). There are also relict populations of species whose "mainland" populations occur hundreds of kilometers to the south in the San Francisco Bay Area and San Joaquin Valley (Anderson 2004). Amphibian and reptile species including the California Slender Salamander (Batrachoseps attenuatus), Sagebrush Lizard (Sceloporus graciosus), Common Sharp-tailed Snake (Contia tenuis), Ring-necked Snake (Diadophis punctatus), Coachwhip (Coluber flagellum), and Long-nosed Snake (Rhinocheilus lecontei) have all been isolated at the Buttes from their "mainland" populations elsewhere in the state, 
either naturally or by anthropogenic habitat manipulation. The unique topography and species assemblage occurring within the Buttes, coupled with the threats to that biota, indicate that special efforts must be taken to learn all we can about this region to best inform conservation and management of this unique place with regard to habitat alteration, invasive species, and potential climate change impacts (Anderson 2004, Sinervo et al. 2010).

The Buttes have also been isolated from systematic scientific study because the entire mountain range has been under private ownership for the past 150 years or more. Little herpetological research has been conducted in the Buttes. Hayes and Cliff (1982) produced a checklist of herpetofaunal species for Butte County and the Butte Sink region, which also included the Sutter Buttes. A few additional studies include ecological investigations focusing on distribution and potential competition between S. graciosus and Western Fence Lizards (Sceloporus occidentalis; Rodgers 1953); phylogenetics of S. graciosus (Boyd 1996); a comparison of femoral pore bilateral asymmetry in S. occidentalis between sexes and between sites (Shedd 2009); and 2 studies of disease-causing organisms found in Western Black-Legged Ticks (Ixodes pacificus) collected from 3 lizard species (Southern Alligator Lizard [Elgaria multicarinata], S. graciosus, and $S$. occidentalis), and 1 snake species, the Western Rattlesnake (Crotalus oreganus; Wright et al. 2003, Nieto et al. 2009). The last 2 studies referenced here utilized individuals of these species from the Buttes as a means of sampling ticks; the authors did not investigate the ecology or biology of the lizards or snakes outside of host-parasite relationships (Wright et al. 2003, Nieto et al. 2009).

These past efforts to study and catalog the herpetofauna of the Buttes have necessarily been opportunistic, and somewhat haphazard. Therefore, much doubt remains as to whether all species present in the Buttes have been detected or whether herpetofaunal species that were recorded decades ago have been since extirpated due to land-use changes, extensive fires that have impacted the area on several occasions, habitat successional changes, or the introduction of exotic plants and animals (Anderson 2004). An example of this is the observation of Blainville's Horned Lizard (Phrynosoma blainvillii) by Marc Hayes, who observed 3 individuals on 2 occasions in 1964 but made no other observations of the species in subsequent visits (Marc Hayes personal communication). Thomas Rodgers, who spent substantial time in the Buttes in the twentieth century, told M. Hayes that during the mid1950s he had seen "half a dozen" P. blainvillii during the peak spring activity period in the same area within the Buttes where Hayes observed the species in the 1960s. No voucher specimen was collected by either researcher (M. Hayes personal communication), and this species has not been reported or apparently observed since Hayes' 1964 sightings. As a result, neither Hayes and Cliff (1982) nor Anderson (2004) included P. blainvillii in their checklists. The current status of this species in the Buttes is unclear. A small population of this extremely cryptic species could easily escape detection; however, it is also possible that habitat changes over the past 50 years could have led to the extirpation of this species from the Buttes. In addition, there are elusive species such as Western Spadefoot (Spea hammondii) and Coast Nightsnake (Hypsiglena ochrorhyncha) which have never been detected in the Buttes despite the presence of appropriate habitat. Trapping techniques employed at study sites are often critical as a means of encountering species that might otherwise go undetected in opportunistic visual encounter surveys (Willson and Gibbons 2009). Thus, for conservation reasons, a systematic investigation of the present-day assemblage of the herpetofauna of the Buttes is warranted, as over 4 decades have elapsed since the time that M. Hayes and T. Rodgers explored the Buttes in earnest (Anderson 2004).

\section{Study Site}

The Buttes are unique in that they are the only significant mountain in the center of the otherwise topographically uniform and lowland Great Central Valley of California (Fig. 1). The entire mountain range lies within Sutter County and consists of an almost perfectly circular ring approximately $16 \mathrm{~km}$ in diameter with the center at $36.22312^{\circ} \mathrm{N}, 121.80834^{\circ} \mathrm{W}$. The Buttes are an extinct volcano, composed primarily of andesite and rhyolite components that were formed approximately 1.6-2 million years ago during the early Pleistocene (Williams 1929, Williams and Curtis 1977). Since volcanic 
activity ceased at the Buttes, natural forces have weathered the mountain into its current complex topography. The highest of many peaks in the small range is South Butte, which is approximately $650 \mathrm{~m}$ above sea level. Having erupted in the center of a valley never connected to any mountain range, the Buttes are effectively what Walt Anderson (2004) described as an "inland island" of montane habitat surrounded by the "sea" of the valley floor. Climatic conditions at the Buttes are typical of inland northern California, with temperatures that range as high as $47^{\circ} \mathrm{C}$ during the summer and as low as $-7{ }^{\circ} \mathrm{C}$ during the winter (Anderson 2004). The Buttes receive an average rainfall of 38-50 cm annually, depending on specific location within the Buttes. The majority of this precipitation falls between December and February, as is typical for California's Mediterranean climate (Anderson 2004). Other than isolated thunderstorms during the summer months, a lack of precipitation between June and the end of October is common. This rainfall pattern causes temporary streams to flow during the winter but not persist through the summer. Light snowfall events in the Buttes are rare (Anderson 2004).

Much of the vegetation in the Buttes comprises nonnative annual grasslands; however, native woodlands, dominated by Blue Oak (Quercus douglasii), are present on north-facing slopes of the mountainous center of the Buttes (Anderson 2004). The terrain in the central region of the Buttes is rugged and steep with dense vegetation on the north-facing slopes of the hills and sparser woody vegetation on the south-facing slopes and on the outer hills. Other conspicuous woodland flora present are Valley Oak (Quercus lobata), Western Redbud (Cercis occidentalis), California Bay Laurel (Umbellularia californica), Common Manzanita (Arctostaphylos manzanita), and Poison Oak (Toxicodendron diversilobum) among many other species (Anderson 2004). Invasive Yellow Star Thistle (Centaurea solstitialis) dominates disturbed sites in the flat open grasslands within the Buttes. Anderson (2004) provides an extensive list of Buttes flora.

Before European settlement of the area, the Buttes were of special significance to many local Native American tribes both as a spiritual place and as a place for gathering resources (Burton 2009). The Buttes are central in many stories from these native peoples and range from the Buttes being the location of the creation of humankind (Dixon 1902) to the Buttes being the sacred place where the dead reside (Burton 2009). Native American use of the area is evident, with many grinding holes found throughout the Buttes (Anderson 2004, Burton 2009). After European settlers arrived, use of the landscape has been mostly for livestock grazing with some mining for rock and natural gas (Anderson 2004). Other uses have included gold mining during California's Gold Rush and, more recently, construction of a radio communication tower on South Butte and the installation of a missile facility during the Cold War (Anderson 2004). Currently, private landowners in the Buttes mostly use their properties for small-scale cattle and sheep grazing or for orchards. Housing development within the Buttes has been limited, but ranch homes are scattered in the outer areas, and there is a golf course on the southern end (Anderson 2004). Landowners who do not use their properties for business purposes retain their properties for hunting and other personal recreation activities.

Access to the Buttes for scientific study has been exceptionally limited for approximately the past 150 years due to the patchwork of privately owned lands in the region. However, in 2003, the California Department of Parks and Recreation (CDPR) purchased a 1785-acre former ranch property in the Buttes and designated the parcel as a state park in 2005 (California Department of Parks and Recreation 2005). Currently, this park does not have an official name; however, it was commonly referred to as Sutter Buttes State Park (SBSP or park) during the course of this work. We have adopted this name herein due to lack of an official alternative. The park area lies on the northern end of the Buttes (Fig. 1) with habitat consisting of open grassland, savannahtype forest, and dense oak woodland forest. The park has numerous small ephemeral streams and one artificial stock pond that measures approximately $60 \times 20 \mathrm{~m}$ at its high water mark. This pond persists during highprecipitation years but can dry completely during low-precipitation or drought years. The park ranges in elevation from $50 \mathrm{~m}$ asl to approximately $350 \mathrm{~m}$ asl. The southern section of the park has steep peaks and deep valleys cut by streams covered in dense oak woodland 
on the north-facing slopes. The center of the park consists of one of the most prominent valleys within the Buttes, known as "Peace Valley," where there are historic ranch structures, a cemetery, and a cattle pond. Finally, the northern section of the park has lower hills covered in oak savannah-type vegetation. As of this writing, the park is not accessible to the general public. This situation presents the exceptional opportunity to study a distinctive habitat and unique assemblage of species in a protected area within a historically inaccessible region. By assessing the community of herpetofauna at SBSP before public access is permitted, we can provide a baseline, previsitation view of the herpetofaunal community that can be used as a comparison for future management and study as the site is developed further for public use.

\section{Objectives}

The establishment of SBSP in 2005 provided both a compelling and immediate need for up-to-date information on the biodiversity of the Buttes, including its herpetofauna. The park provided the ideal location to conduct herpetofaunal surveys in this area that had previously been inaccessible due to private-property access issues. Additionally, access to the park property allowed us to conduct the first systematic herpetological inventory utilizing a variety of sampling methods. Our 2 objectives for this study were designed to further the knowledge of the unique biota of the Buttes as a whole and contribute to future conservation of the herpetofauna in the park:

OвJестіve I.-Verify presence of each amphibian and reptile species listed in the most recent species checklist compiled by Anderson (2004) from previous published works and observations within SBSP. This effort would provide CDPR a list of species known to inhabit the park area specifically and would identify any special state or federally protected species in the park for which special conservation measures should be taken. An updated species checklist would also provide an updated baseline of the species assemblage for comparison in the future.

OBjective II.-Catalog known museum records for the Buttes from all sources including major universities, and research museums, as well as smaller collections. This cataloging would investigate species representation for future research and identify species that potentially inhabit the park. By providing this information, we hope to spark further museum-based research on wellrepresented species, and identify species that are not currently represented by museum vouchers and tissue samples.

\section{Methods}

In this study, we utilized a variety of herpetological survey methods that were most likely to be effective for a wide variety of species in a variety of habitats and logistically practical to implement at SBSP. These methods included drift fence arrays, coverboard arrays, underwater turtle traps, night driving, and opportunistic visual encounters

Spatial distribution of traps within the park was an important consideration when we installed drift fence and coverboard arrays (Fig. 1). We deployed traps across habitat types and geographic locations to maximize the chance of encountering all possible species in the park. To allow qualitative comparisons of sampling methods, we paired each drift fence with a nearby coverboard array in a similar habitat. The first consideration for trap placement was by geographic location within the park. We divided the park into 3 sections-North, Center, and South-which corresponded to Williams's "Rampart," "Moat," and "Castle" analogy for the Buttes (Williams 1929, Williams and Curtis 1977). Within each of these 3 geographic/topographic regions, we deployed 2 drift fence/coverboard pairs, one in each of the predominant habitat types (grasslands and woodlands). In this way, 2 of each trap type were present in each geographic location, and 3 of each type of trap were present in woodland habitats and 3 in grassland habitats. Finer-scale trap location was based on accessibility and concealment from the public. Sampling occurred at SBSP from June 2006 to October 2006, and again from February 2007 to May 2007.

\section{Drift Fences}

We constructed 6 drift fence arrays similar to those used by Fisher et al. (2008) in the park in June 2006. Each drift fence array consisted of 3 fences made of $90 \%$ shade cloth (Wind and Shade Screens, San Marcos, CA, Reptile Fence) each measuring $15 \mathrm{~m}$ long by 
$0.3 \mathrm{~m}$ high, and placed at $120^{\circ}$ angles from one another. We buried a 5-gallon bucket in the ground at the center of each array, and at the end of each fence of the array. The lids for the 5-gallon buckets had wooden blocks screwed onto them such that there was a $4-\mathrm{cm}$ space between the ground and the lid when the trap was open. The lid could be turned over and sealed to the bucket when the trap was not in use. Each lid had a length of jute twine stapled to one of the wooden blocks so that the twine would drop into the bucket, thus giving entrapped mammals a means of escape (Karraker 2001). We placed a Gee Crawdad Funnel Trap (Memphis Net and Twine \#G40CF) in the middle of each arm in each array on each side of the fence. We covered funnel traps with $0.6-\mathrm{cm}$ plywood to provide shade. We secured each funnel trap next to the array with 3 stakes, to hold it up against the fence and to keep the trap from sliding up or down the length of the fence. We filled any space between the trap and the fence with dirt to provide a ramp that further directed animals into the trap. A moistened sponge was placed inside each bucket and each funnel trap to prevent desiccation of captured animals. We opened drift fences once a week, checked the arrays on the following 2 days, and then closed the traps until the next sampling period. We sampled drift fences from the end of June 2006 to the first weekend of October 2006 and from February 2007 to May 2007.

\section{Coverboards}

We placed 60 coverboards in the Park during June 2006. We divided these into 6 linear arrays of 10 boards, each with boards placed $10 \mathrm{~m}$ apart from one another. We constructed each board from $0.6-\mathrm{cm}$ plywood cut to $1 \times 1 \mathrm{~m}$. We evenly divided the 6 arrays into woodland and grassland habitats and paired each array with a nearby drift fence in similar habitat. We sampled coverboards once a week. Studies show that sampling once a week is the most effective sampling frequency, because animals are not discouraged from colonizing the boards by oversampling, but the boards are sampled with enough frequency to provide a reasonable quantity of data (Fellers and Drost 1994, Marsh and Goicochea 2003). We used coverboards as a sampling method from June 2006 until the end of sampling in May 2007.
Turtle Traps

Turtle traps used in this study measured $95 \times 55 \times 30 \mathrm{~cm}(\mathrm{~L} \times \mathrm{W} \times \mathrm{H})$ and had an opening on 2 ends measuring $50 \mathrm{~cm}$ wide. The opening can stretch to $20 \mathrm{~cm}$ high when a turtle enters the trap, but then closes behind the turtle to prevent escape. The trap has a metal frame covered with $4 \times 3$-cm mesh. We used 4 of these traps during each sample period. Previous studies of Western Pond Turtle (Emys marmorata) show that this type of trap is an effective means of trapping turtles (Spinks et al. 2003). We positioned traps in shallow-enough water to allow $2 \mathrm{~cm}$ of the top of the turtle trap to extend above the water. This arrangement allowed for increased sampling hours, as turtles could safely remain in the traps overnight without risk of drowning. We used a variety of baits in the traps including chicken parts, beef liver, beef tripe, anchovies, sardines, and different combinations of these baits. We placed traps in the stock pond at the center of the park during September and October 2006 and again in April and May 2007. During those months we sampled for 2 days per week for 10 weeks, yielding a total of 80 trap days.

\section{Night Driving}

Night driving, sometimes referred to as "road cruising," is perhaps the most effective means of sampling snakes when environmental conditions are favorable (Sullivan 1981, Shaffer and Juterbock 1994, Fahrig et al. 1995, Sullivan 2000). There are currently no paved roads within SBSP. We generated a list of species captured while we drove other paved roads that surround and bisect the Buttes. We conducted night driving surveys at the Buttes during this study in June 2007 along Pass Road and West Butte Road, each of which is approximately $7 \mathrm{~km}$ from the park.

\section{Visual Encounter Surveys}

Extensive visual encounter surveys were conducted opportunistically during travel between sites in the park and during directed effort to encounter particular species of interest such as B. attenuatus or D. punctatus that might not be observed with other methods. Visual encounters included flipping cover objects such as logs, large rocks, or man-made materials. Although more extensive systematic visual encounter studies have proven 
useful in a number of studies (Crump and Scott 1994, Doan 2003), during this study they were not practicable due to limited onsite time and other logistical constraints.

\section{Data Collection}

The following data were collected for each captured animal: snout-vent length (SVL), tail length, and mass. We took GPS coordinates using a Garmin Geko 101 (Garmin, Olathe, KS) receiver. Animals were individually marked using either toe-clipping or passive integrated transponders (PIT tags). Snakes $>100 \mathrm{~mm}$ SVL were marked using PIT tags, which are an effective permanent mark (Gibbons and Andrews 2004). When possible, we collected tissue samples from each captured animal and preserved the samples in 95\% ethanol. All tissue samples from this study are currently in long-term storage at H. Bradley Shaffer's Lab (HBS) at the University of California, Los Angeles (UCLA). When possible, photos of species taken during this study were deposited in CalPhotos (http://calphotos.berkeley .edu), a photo database hosted by University of California, Berkeley. We made every effort to ensure that these photographs clearly depict the subject individual so that verification of the species within SBSP is undisputable.

\section{RESUlTS}

\section{Objective I}

We verified the presence of 14 herpetofaunal species that were previously recorded at the Buttes within the boundaries of the SBSP, and detected one species, the Pond Slider (Trachemys scripta), that had not previously been recorded in the Buttes. Additionally, in 2012 after completion of the primary fieldwork portion of this study, Glenn Woodruff and the second author observed a C. flagellum in the park and took a photo voucher of the individual (CalPhotos ID: 000000000116 0461). During the same site visit, they observed a California Kingsnake (Lampropeltis californiae) within the park boundaries. Thus, 17 species were detected (Table 1). A final checklist of species encountered during this study, or thought to occur within the park, is in Appendix 1.

An accumulation curve of species detection based on drift fence and coverboard captures in combination with visual detections during the primary study period of 2006-2007 showed that visual encounters detected the most species in the shortest amount of time and detected the most species overall (Fig. 2). Peak detections occurred across all survey methods during spring and gradually declined throughout summer and into fall, similar to the results found in Todd et al. (2007). Visual encounters for most species coincided with the trap captures of those species; however, visual encounters had a longer period over which detections were recorded than any other method. All species that were detected by drift fences and/or coverboards were also detected with visual encounters.

\section{Objective II}

We searched for and verified all known university and museum voucher specimens for the Buttes. Eight collections have preserved 1024 individual herpetofauna specimens representing 16 of 21 possible species (Table 2). Two research labs-the lab of Dr. H. Bradley Shaffer (HBS) and the University of California, Berkeley, Museum of Vertebrate Zoology (MVZ)-have preserved 149 tissue samples from 11 of 21 possible species (Table 2), with all of the HBS samples coming from this study. All institution codes follow Pérez (2014), except the California State University, Chico Vertebrate Museum (CSUCVM), which was not listed, and H. Bradley Shaffer's Lab at UCLA, to which we assigned the code HBS. Correct identification for all specimens was verified either by one of the authors (EO) or by qualified on-site curatorial staff.

Collection locations of most of these specimens are from areas in the Buttes that lie outside the current SBSP boundaries with the exception of 2 B. attenuatus (MVZ 37483, 37484) collected in 1942 by Thomas Rodgers in Peace Valley, which is now a part of SBSP. Other areas within the Buttes represented within the museum databases include South Butte, Craggy Ridge, Dean Place, and several localities to the south and west of the park.

\section{Discussion}

\section{Objective I}

Previously published checklists (Hayes and Cliff 1982, Anderson 2004) and expert opinion indicated that 22 species of amphibians and reptiles were, or had been, present in the Buttes. Interviews with Walt Anderson revealed 


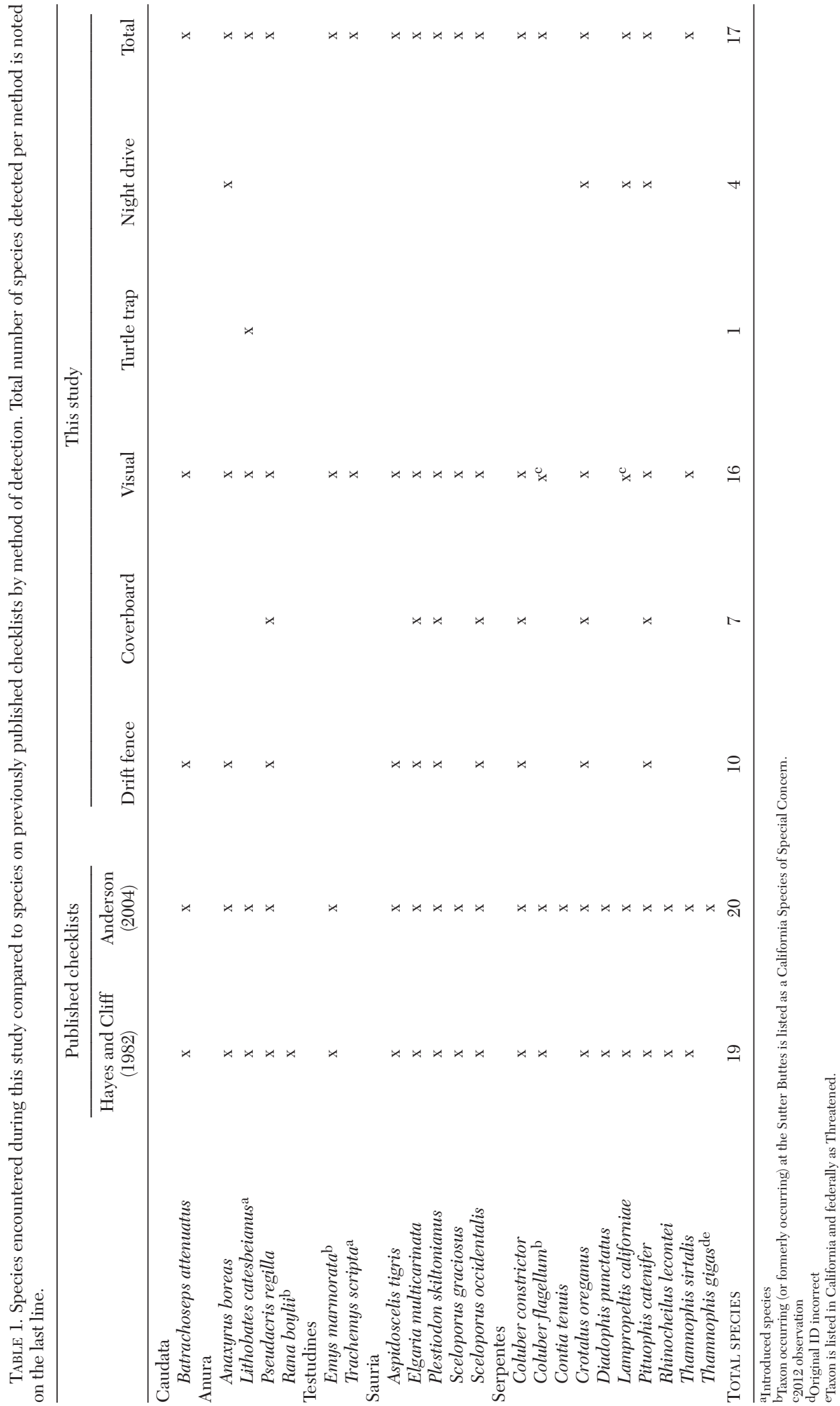




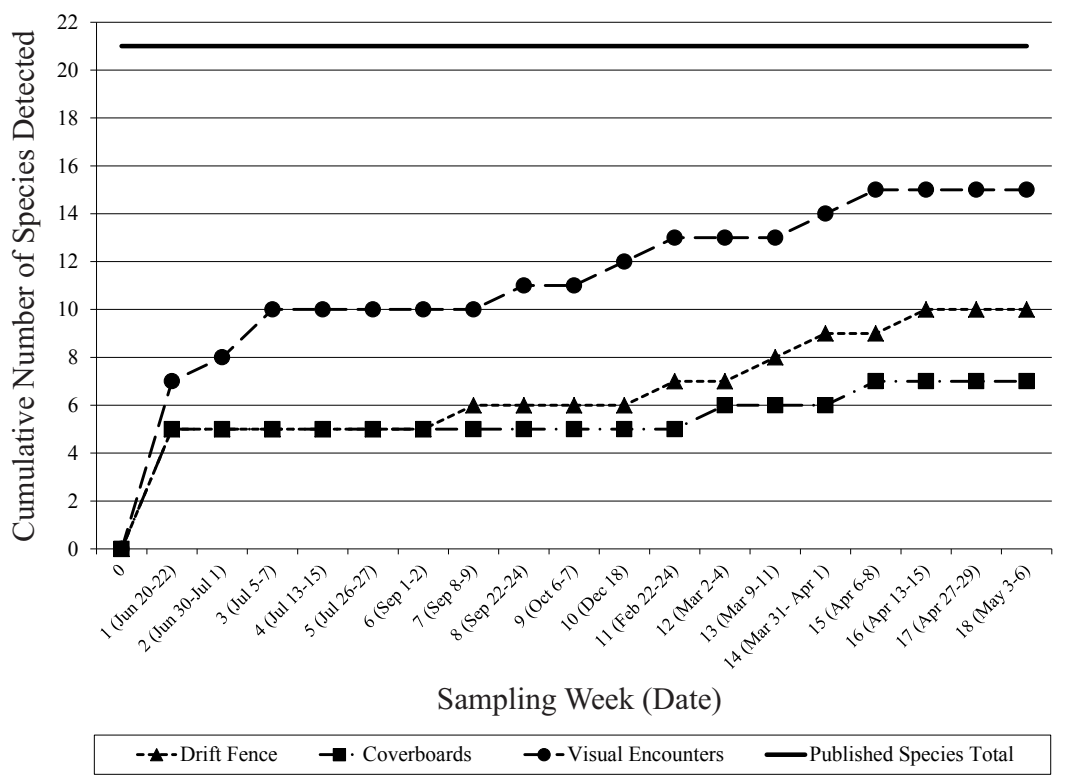

Fig. 2. Number of species cumulatively detected with the 3 most productive sampling methods over time (20062007). The data set excludes the 2012 Coachwhip (Coluber flagellum) and California Kingsnake (Lampropeltis californiae) observations.

that one species, the Giant Gartersnake (Thamnophis gigas), which is listed in his 2004 book as being present in the Buttes, was actually a misidentified Common Gartersnake (Thamnophis sirtalis); thus, T. gigas should no longer be considered as having ever been recorded in the Buttes (Walt Anderson personal communication). The clarification of the correct identification is crucial because T. gigas is federally and state listed as a threatened species. The presence of this species within the Buttes would have significant repercussions both for management of the park and for management of T. gigas as a whole. During the initial study period between 2006 and 2007, we observed 14 previously recorded species and 1 new species, the now widely invasive $T$. scripta. Observations of 2 additional species during another site visit in 2012 bring this confirmed total to 17 species of amphibians and reptiles at SBSP.

During this study, 6 species that have been previously recorded within the Buttes were not found in the boundaries of the park. As described above, we found that T. gigas was misidentified and should not be considered to have ever been present. Foothill YellowLegged Frog (Rana boylii), and P. blainvillii appear to no longer occupy the SBSP area. We have strong evidence that 3 additional undetected species D. punctatus, R. lecontei, and C. tenuis are present at SBSP. The addition of these 3 species brings our final species checklist for SBSP to 20 species (Appendix 1). We may not have detected these 3 snake species for a variety of reasons, one of which is the unusual weather patterns during our sampling. The spring of 2006 was unusually wet, and access to the park was limited due to poor road conditions. Once the wet season ended in early June, the quick onset of summer temperatures resulted in shortened spring activity patterns for many species. These snakes are surface active in the spring and so this weather pattern was not conducive to observing these species. The winter and spring of 2007 were also unusual. The relatively wet spring of 2006, was followed by an atypically dry year in 2007, again curtailing the spring activity period of most snakes. This set of weather patterns over the 2 years sampled almost certainly had a negative effect on snake surface activity and thus on the number of snake observations during this study.

The first of these undetected, but believedpresent species is D. punctatus. Although we did not observe this species during our fieldwork, a D. punctatus individual was 


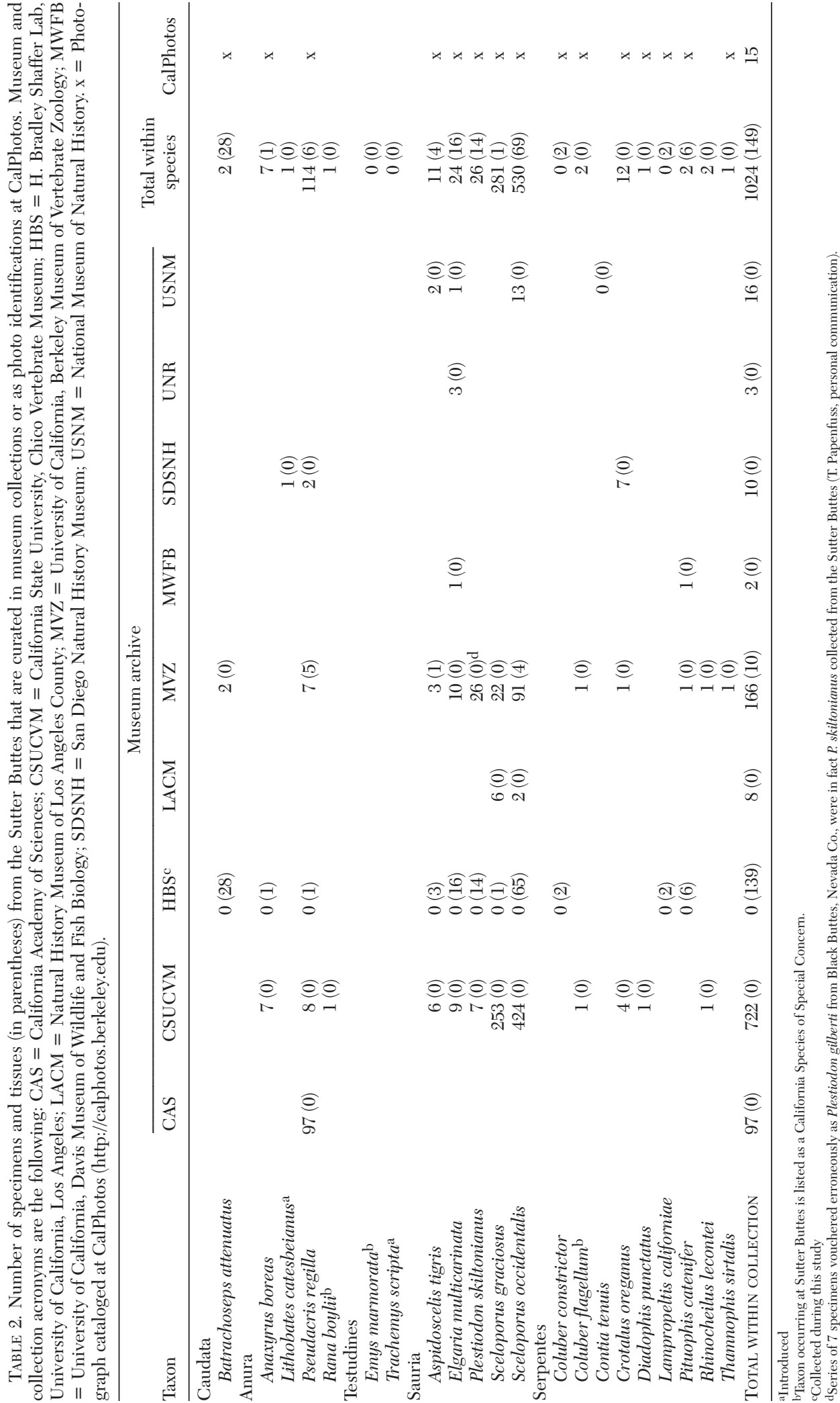


photographed by State Park Biologist Jim Dempsey (CDPR) inside the park in October 2005 shortly before our study commenced (CalPhotos ID: 000000001107 1609). Photographs of the specimen clearly confirm the identification is correct, and so we corroborate the presence of D. punctatus within the park.

The second species, R. lecontei, was observed by a neighboring landowner Howard Hamman adjacent to the park during spring 2007. Based on his detailed description of the animal's appearance during an interview with us, we feel confident that his observation was valid. Mr. Hamman is a long-term landowner in the Buttes who is very familiar with the common snakes in the area. He noted that the snake he observed was not any species he was familiar with and he stated that he was certain that it was not $C$. oreganus, T. sirtalis, L. californiae, or Gophersnake (Pituophis catenifer). The observation occurred approximately $800 \mathrm{~m}$ west of the park boundary. Based on these lines of evidence, and that $R$. leconte $i$ was previously recorded in the Buttes, we believe this species should be included in the final checklist for the park, though this determination is subject to verification.

The final unobserved species is C. tenuis. There is one confirmed observation of an individual of this species at the Buttes (Anderson 2004). This observation occurred in 2003 in Hough Canyon, which lies just south of the SBSP in the direct center of the Buttes (Anderson 2004). Contia tenuis is a small, fossorial snake that exhibits restricted surface activity; thus, visual observation of this secretive species in the open is very rare. The species is typically observed by searching under debris and cover objects during late winter and spring (Hoyer et al. 2006). Contia tenuis prefers mesic microhabitats (Stebbins 2003) similar to those used by B. attenuatus, which we did find in the park and in other areas where this small snake co-occurs with $B$. attenuatus. Even in areas where C. tenuis is common, the combination of fossorial habits, microhabitat requirements, and limited surface activity can often make observation of this species difficult. It is possible that $C$. tenuis is present but at low densities in the Buttes, and this warrants further investigation. It is also possible that the coverboard arrays that were placed in June 2006 simply were not well enough established to provide appropriate microhabitat for C. tenuis. In the future with more "weathering" of the coverboards, C. tenuis may be encountered more readily. Large groves of $Q$. douglasii within the southern portion of the park were occupied by B. attenuatus, and we suspect that further focused survey efforts of favorable microhabitats will confirm C. tenuis within this area of SBSP.

Rana boylii is the only previously reported species (Hayes and Cliff 1982) that we did not observe and do not believe inhabits the Buttes. Rana boylii is listed as a Species of Special Concern in the state of California; thus the presence or absence of this population has important management implications both for the park and for the species as a whole. The CSUCVM has the only existing Sutter Buttes museum voucher for this species. The specimen was originally collected in 1951 by a "B. Kamp" and originally identified as a Red-legged Frog (Rana aurora, sensu lato). M. Hayes corrected the identification to $R$. boylii, and the authors independently examined this specimen and confirmed the identification. The specimen was collected from Dean Place, adjacent to and just south of SBSP. To our knowledge there have been no other individuals sighted since that time. Extensive searches in the park's flowing streams during September 2006 and throughout the spring of 2007 yielded no sightings or audible vocalizations of this species. It is important to note that winter 2006 had unusually high precipitation, but by September 2006 , only a few pools of water persisted in the park. All of these pools were then used as wallows by feral pigs (Sus scrofa), which were introduced into the Buttes in the late 1970s (Anderson personal communication) and are now abundant throughout the Buttes. Rana boylii requires permanent flowing water (Jennings and Hayes 1994), and thus would have a difficult time persisting in the Buttes due to the lack of this habitat type (Anderson 2004). During summer, most creeks and drainages within the Buttes dry completely, and S. scrofa uses any pools of water left in the drying streams as wallows. It is our opinion that this is not conducive to the reproductive ecology or survival of $R$. boylii. This combination of factors has likely led to the extirpation of $R$. boylii from the Buttes and at this time warrants their exclusion from the final SBSP checklist of herpetofaunal species. If $R$. boylii 
is ever discovered in SBSP, or rediscovered anywhere in the Buttes, careful and extensive management will be required to ensure its survival.

The possibility that $P$. blainvillii could exist within the Buttes is based on a few personal observations of noted herpetologists Dr. Thomas Rodgers and Dr. Marc Hayes in the 1950s and 1960s, and we consider these reports credible. Although it is possible that a small population has remained extant within the Buttes, this seems unlikely considering microhabitat changes within the Buttes, especially the widespread invasion of nonnative grasses and $C$. solstitialis, and significant population declines of this species throughout its range in Northern California (Jennings and Hayes 1994). Further directed survey efforts in the Buttes may yield observations of this species, but without a voucher specimen on record or a recent confirmed observation, we cannot include this species in our final species list and must consider the possibility that this potentially unique population has been extirpated from the Buttes.

Although our aquatic trapping effort proved unsuccessful in capturing any turtles, we did capture numerous American Bullfrogs (Lithobates catesbeianus) in traps, and we did visually observe an adult $T$. scripta basking on a rock at the cattle pond in 2006 . The turtle was identified as T. scripta rather than E. marmorata based on large size, a dark-colored carapace, and a faded postocular patch. However, further surveys will be required to confirm that $T$. scripta has successfully established itself in the Buttes, and our inclusion of this species at SBSP should be considered preliminary and subject to further verification. Another turtle reliably identified as E. marmorata was observed for several minutes by William Haas and others in April 2007 at the park's cattle pond from a distance requiring binoculars. Due to W. Haas's extensive work on E. marmorata and his extended observation of the individual, we believe this identification to be valid, and thus we include both species of turtle in our list of species found in the park.

\section{Comparison of Survey Methods}

Each survey method used in this study detected different proportions of the amphibian and reptile species assemblage. The order of effectiveness of each method in total amphibian and reptile species detection percentage was as follows: visual encounter surveys, $94 \%$; drift fences, $58 \%$; coverboards, $41 \%$; night driving, 23\%; and turtle trapping, 5\%. We captured more individuals in drift fences than under wooden coverboards or by other methods. The one species that did not follow this pattern was E. multicarinata, which we captured more commonly under coverboards. We found coverboards to be very effective in capturing E. multicarinata, in contrast to other studies that found wooden coverboards to be ineffective in sampling Elgaria (Adams et al. 1999). We used night driving sparingly during this study. Nighttime access to the park was limited, so night driving the park's roads was not possible. As a substitute, we drove Pass Road to the south of the park for several nights in June 2007. This sampling method detected C. oreganus, L. californiae, P. catenifer, and Western Toads (Anaxyrus boreas). Once the park is open to the public, night driving the roadways within the park may provide researchers with the opportunity to observe snakes as a supplement to the methods used during this study, which did not result in a large number of snake observations. The presence of these species on the roads indicates that road mortality could be an important consideration in the future when public access is established in the park.

Overall, visual encounter surveys were the most effective means of detecting species, followed by drift fences and then coverboards (Fig. 2). Visual encounter surveys were especially successful for detecting $B$. attenuatus, all species of anuran, and the 2 species of turtles. Visual encounter surveys were also more effective in documenting diversity of snakes compared to trapping arrays. Visual encounter surveys were an indispensable tool in this study and should continue to be used in future studies of these populations.

Although less effective in overall detection of species diversity, the 2 terrestrial trapping methods are more easily standardized and could serve as useful tools for statistical comparison of spatial data and long-term monitoring. Although our comparisons must be viewed as preliminary based on the small number of sites and trap arrays that we deployed, we did detect statistically significant differences in the composition of species captured based on geographic 
location among the park's 3 geographic regions $(G=34.3, \mathrm{df}=18, P=0.01)$ (Olson 2007). We also observed a significant difference in the composition of species captured between drift fences and coverboards $(G=36.4$, df $=$ $9, P<0.01)$. Specifically, E. multicarinata was more commonly encountered under coverboards (Olson 2007). These preliminary results could be informative specifically for the management of this property but also in terms of validating trapping techniques in different types of habitats. A detailed discussion of both the biological factors and limitations of our experimental design that may have contributed to these results is provided in Olson (2007).

\section{Objective II}

Searching the VertNet (http://www.vertnet .org) database proved the most effective means of searching various museum catalogs for specimens from the Buttes. For collections not cataloged in VertNet but likely to have specimens from the Buttes, we contacted curators for those facilities and searched their collections for any possible specimens from the Buttes. These collections included Sonoma State University, California State University-Sacramento, Sierra College, Humboldt State University, Butte College, UCLA, and San Francisco State University. Most specimens are housed at the CSUCVM (722) or at the MVZ (159) (Table 2). A full list of institutions with both whole specimens and preserved tissue samples is provided in Table 2 . By far, the most extensive collection of Buttes herpetofaunal specimens is located at the CSUCVM. At this time, the museum herpetological catalog is not accessible through online search engines such as VertNet; however, the museum is beginning the process of adding the entire CSUCVM catalog to the VertNet database (J. Bogiatto personal communication). No museum vouchers exist for 3 species of snakes-North American Racer (Coluber constrictor), C. tenuis, and L. californiae-and only 4 of 8 snake species are represented as preserved tissue samples. There are also no museum vouchers for either of the 2 testudine species from the Buttes.

\section{Summary and Conclusions}

The combination of geologic history and human history has created a unique environment in the Buttes. This unusual environment supports a unique herpetofaunal community (Stebbins 2003). Because of limited development, the Buttes act as a sanctuary within the heavily modified Central Valley and deserve protection. This study has (1) provided muchneeded updates for previously published species lists for the Buttes, (2) located and validated all museum records for the region, and (3) provided a baseline for species diversity with information on distribution and abundance within the only publically protected site in the Buttes (i.e., SBSP). Most species known from the Buttes are represented in museum collections with full specimens and/or with tissue samples. Efforts should be taken to complete the museum collections so that permanent vouchers of each species can be available for further research.

Six extant and 2 apparently extinct herpetofaunal species present in the Buttes are isolated from their "mainland" ranges. The extant species (B. attenuatus, S. graciosus, C. flagellum, C. tenuis, D. punctatus, and $R$. lecontei) deserve focused management and preservation of these isolates, as they will be vulnerable to habitat changes and invasive species, such as L. catesbeianus and S. scrofa, as well as potentially susceptible to the effects of climate change. Additional study may reveal one or more of these isolated populations as unique genetic lineages.

The Buttes truly are a unique habitat worthy of further scientific study and conservation. Without learning more about the species, including the herpetofauna, that inhabit the Buttes, effective future conservation will be challenging. It would be a disservice to future generations if the integrity of this special place were compromised by the juggernaut of development that is rapidly encroaching upon the Buttes.

\section{ACKNOWLEDGMENTS}

We thank Colleen Hatfield and Don Miller for their assistance in developing this study. We thank the California Department of Parks and Recreation (CDPR), Woody Elliot, Tim Davis, and Jim Dempsey for permitting access to the study site. Historical and observational information from Walt Anderson and Marc Hayes was invaluable, as well as the field notes from Thomas Rodgers (deceased). The assistance of the following museum curators 
was especially helpful: Jay Bogiatto (CSUCVM), Irene Engilis (MWFB), Chris Feldman and Erica Ely (UNR), Bradford Hollingsworth and Laura Kabes (SDSNH), Greg Pauly (LACM), Carol Spencer (MVZ), Kenneth Tighe and James Poindexter (USNM), and Jens Vindum (CAS). The California State Parks Foundation, the American Museum of Natural History Theodore Roosevelt Memorial Grant, and the California State University, Chico Research Foundation provided funding for this project. We especially thank the numerous volunteersyou know who you are-who donated their time, energy, and sweat to make this study possible. E. Olson especially would like to thank H. Bradley Shaffer for his inspiration and mentorship. All work was conducted under California Department of Fish and Wildlife Scientific Collection Permit \#SC-6660.

\section{Literature Cited}

Adams, M.J., S.D. West, and L. Kalmbach. 1999. Amphibian and reptile surveys of U.S. Navy lands on the Kitsap and Toandos Peninsulas, Washington. Northwestern Naturalist 80:1-7.

Anderson, W. 2004. Inland island: the Sutter Buttes. The Natural Selection, Prescott, AZ, and the Middle Mountain Foundation, Live Oak, CA.

BoyD, M.R. 1996. Intraspecific genetic diversity and divergence of geographically isolated populations of Sceloporus graciosus gracilis using random amplified polymorphic DNA. Master's thesis, California State University, Chico, CA. 55 pp.

Burton, M.B. 2009. Multiple ways of seeing one place: archaeological and cultural landscapes of the Sutter Buttes, California. Master's thesis, California State University, Chico, CA. 246 pp.

California Department of Parks and Recreation. 2005. The Sutter Buttes project: classification and naming document.

Crump, M.L., and N.J. ScotT. 1994. Visual encounter surveys. Pages 84-92 in W.R. Heyer, M.A. Donnelly, R.W. McDiarmid, L.C. Hayek, and M.S. Foster, editors, Measuring and monitoring biological diversity: standard methods for amphibians. Smithsonian Institution Press, Washington, DC.

Dixon, R.B. 1902. The Huntington California Expedition: Maidu myths. Bulletin of the American Museum of Natural History 17 (Part 2):33-118.

DOAN, T.M. 2003. Which methods are most effective for surveying rain forest herpetofuana? Journal of Herpetology 37:72-81.

Fahrig, L., J.H. Pedlar, S.E. Pope, P.D. Taylor, and J.F. WEGNER. 1995. Effect of road traffic on amphibian density. Biological Conservation 73:177-182.

Fellers, G.M., and C.A. Drost. 1994. Sampling with artificial cover. Pages 146-150 in W.R. Heyer, M.A. Donnelly, R.W. McDiarmid, L.C. Hayek, and M.S. Foster, editors, Measuring and monitoring biological diversity: standard methods for amphibians. Smithsonian Institution Press, Washington, DC.
Fisher, R., D. Stokes, C. Rochester, C. Brehme, S. Hathaway, and T. CaSe. 2008. Herpetological monitoring using a pitfall trapping design in southern California. U.S. Geological Survey Techniques and Methods 2-A5. 44 pp.

Gibbons, J.W., AND K.M. Andrews. 2004. PIT tagging: simple technology at its best. BioScience 54:447-454.

Hayes, M., AND F. Cliff. 1982. A checklist of the herpetofauna of Butte County, the Butte Sink and Sutter Buttes, California. Herpetological Review 13:85-87.

Hoyer, R.F., R.P. O’DONNEll, and R.T. Mason. 2006. Current distribution and status of sharp-tailed snakes (Contia tenuis) in Oregon. Northwestern Naturalist 87:195-202.

Jennings, M.R., AND M.P. HAYES. 1994. Amphibian and reptile Species of Special Concern in California. Report for the California Department of Fish and Game.

KARRAKER, N.E. 2001. String theory: reducing mortality of mammals in pitfall traps. Wildlife Society Bulletin 29:1158-1162.

Marsh, D.M., and M.A. Goicochea. 2003. Monitoring terrestrial salamanders: biases caused by intense sampling and choice of cover objects. Journal of Herpetology 37:460-466.

Nieto, N.C., J.E. Foley, J. Battaso, and R.S. Lane. 2009. Reptile infection with Anaplasma phagocytophilum the causative agent of granulocytic anaplasmosis. Journal of Parasitology 95:1165-1170.

OLSON, E.O. 2007. The herpetofauna of Sutter Buttes State Park. Master's thesis, California State University, Chico, CA. 91 pp.

PÉrez, M.H., EDITOR. 2014. Standard symbolic codes for institutional resource collections in herpetology and ichthyology: an online reference. Version 5.0. American Society of Icthyologists and Herpetologists, Washington, DC; [accessed 22 September 2014]. http://www.asih.org/

Rodgers, T.L. 1953. Responses of two closely related species of lizards (genus Sceloporus) to different environmental conditions. Doctoral dissertation, University of California, Berkeley, CA. $170 \mathrm{pp}$.

Shaffer, H.B., AND J.E. Juterbock. 1994. Night driving. Pages 163-166 in W.R. Heyer, M.A. Donnelly, R.W. McDiarmid, L.C. Hayek, and M.S. Foster, editors, Measuring and monitoring biological diversity: standard methods for amphibians. Smithsonian Institution Press, Washington, DC.

SHEDD, J.D. 2009. Bilateral asymmetry in two secondary sexual characters in the western fence lizard (Sceloporus occidentalis): implications for correlations with lateralized aggression. Master's thesis, California State University, Chico, CA. 52 pp.

Sinervo, B., F. Méndez-De la Cruz, D.B. Miles, B. Heulin, E. BastiaAns, M. Villagrán-Santa Cruz, R. Lara-Resendiz, N. Martínez-Méndez, M.L. Calderón-Espinosa, R.N. Mesa-Lázaro, et al. 2010. Erosion of lizard diversity by climate change and altered thermal niches. Science 328:894-899.

Spinks, P.Q., G.B. Pauly, J.J. Crayon, and H.B. Shaffer. 2003. Survival of the western pond turtle (Emys marmorata) in an urban California environment. Biological Conservation 113:257-267.

StebBins, R.C. 2003. Western reptiles and amphibians. Houghton Mifflin Company, New York, NY.

SulLivan, B.K. 1981. Distribution and relative abundance of snakes along a transect in California. Journal of Herpetology 15:245-246. 
SULLIVAN, B.K. 2000. Long-term shifts in snake populations: a California site revisited. Biological Conservation 94:321-325.

TodD, B.D., C.T. Winne, J.D. WiLlson, And J.W. GibBons. 2007. Getting the drift: examining the effects of timing, trap type, and taxon on herpetofaunal drift fence surveys. American Midland Naturalist 158:292-305.

Williams, H. 1929. Geology of the Marysville Buttes: California. University of California Publications: Bulletin of the Department of Geological Sciences 18:101-221.

Williams, H., AND G.H. CurTis. 1977. The Sutter Buttes of California: a study in Plio-Pleistocene volcanism. University of California Publications in Geological Sciences 116.
Willson, J.D., and J.W. Gibbons. 2009. Drift fences, coverboards, and other traps. Pages 229-245 in C.K. Dodd Jr., editor, Amphibian ecology and conservation: a handbook of techniques. Oxford University Press, Oxford, England.

Wright, S.A., D.A. Lemenager, R.L. McBride, and D.A. BRown. 2003. The western black-legged tick (Ixodes pacificus) in the Sutter Buttes. Journal of Vector Ecology 28:171-174.

Received 25 September 2015 Accepted 21 March 2016

Appendix 1. Species list for Sutter Buttes State Park, California. Class, order, family, and binomial names are given.

\begin{tabular}{|c|c|}
\hline Scientific name & Common name \\
\hline $\begin{array}{l}\text { AMPHIBIA } \\
\text { Caudata } \\
\text { Plethodontidae } \\
\text { Batrachoseps attenuatus } \\
\text { Anura } \\
\text { Bufonidae } \\
\text { Anaxyrus boreas } \\
\text { Hylidae } \\
\text { Pseudacris regilla } \\
\text { Ranidae } \\
\text { Lithobates catesbeianus } \\
\text { a }\end{array}$ & $\begin{array}{l}\text { AMPHIBIANS } \\
\text { Salamanders } \\
\text { Lungless Salamander Family } \\
\text { California Slender Salamander } \\
\text { Frogs and Toads } \\
\text { Toad Family } \\
\text { Western Toad } \\
\text { Treefrog Family } \\
\text { Pacific Treefrog } \\
\text { True Frog Family } \\
\text { American Bullfroga }\end{array}$ \\
\hline $\begin{array}{l}\text { REPTILIA } \\
\text { Testudines } \\
\text { Emydidae } \\
\text { Emys marmorata }{ }^{\text {bd }} \\
\text { Trachemys scripta }{ }^{\text {ab }}\end{array}$ & $\begin{array}{l}\text { REPTILES } \\
\text { Turtles } \\
\text { Freshwater Turtles } \\
\text { Western Pond Turtlebd } \\
\text { Pond Slider }{ }^{\text {ab }}\end{array}$ \\
\hline $\begin{array}{l}\text { Squamata } \\
\text { Anguidae } \\
\text { Elgaria multicarinata }\end{array}$ & $\begin{array}{l}\text { Lizards and Snakes } \\
\text { Alligator Lizards } \\
\text { Southern Alligator Lizard }\end{array}$ \\
\hline $\begin{array}{l}\text { Phrynosomatidae } \\
\text { Sceloporus graciosus } \\
\text { Sceloporus occidentalis }\end{array}$ & $\begin{array}{l}\text { Iguanid Lizards } \\
\text { Sagebrush Lizard } \\
\text { Western Fence Lizard }\end{array}$ \\
\hline $\begin{array}{l}\text { Scincidae } \\
\quad \text { Plestiodon skiltonianus }\end{array}$ & $\begin{array}{l}\text { Skinks } \\
\text { Western Skink }\end{array}$ \\
\hline $\begin{array}{l}\text { Teiidae } \\
\quad \text { Aspidoscelis tigris }\end{array}$ & $\begin{array}{l}\text { Whiptails } \\
\text { Tiger Whiptail }\end{array}$ \\
\hline Colubridae & Colubrid Snakes \\
\hline $\begin{array}{l}\text { Coluber constrictor } \\
\text { Coluber flagellum } \mathrm{d}\end{array}$ & $\begin{array}{l}\text { North American Racer } \\
\text { Coachwhipd }\end{array}$ \\
\hline Contia tenuis ${ }^{\mathrm{c}}$ & Common Sharp-tailed Snake \\
\hline Diadophis punctatus & Ring-necked Snake \\
\hline Lampropeltis californiae & California Kingsnake \\
\hline Pituophis catenifer & Gophersnake \\
\hline Rhinocheilus leconte $i^{\mathrm{c}}$ & Long-nosed Snake \\
\hline Thamnophis sirtalis & Common Gartersnake \\
\hline Viperidae & Pit Vipers \\
\hline Crotalus oreganus & Western Rattlesnake \\
\hline
\end{tabular}

